\title{
Evaluating the Quality of Tourism and Hotels Academic Departments (Case Study on Faculty of Tourism and Hotels, University of Sadat City)
}

\author{
Mohamed Abou Taleb Mohamed \\ Toka Mahrous Fahmi \\ Hotel Studies Department \\ Tourism Studies Department
}

University of Sadat City

\begin{abstract}
Measuring the quality of academic departments received little attention due to their complex nature, lack of clear-cut quality standards and difficulty to measure their outputs. However, identifying the Standards for Program Accreditation can help measuring the performance of academic departments and assess whether they meet their set objectives and foster an environment of continuous improvement. The objective of this paper is to evaluate the quality of tourism and hotels academic departments utilizing the Standards for Program Accreditation launched by NQAAE. An instrument for measuring the quality of programs in tourism and hotels was developed from these standards and used to assess the quality of tourism and hotels academic departments in the faculty of Tourism and Hotels, University of Sadat City as a case study. Results revealed that both programs need more efforts to be put to fill the gaps in two dimensions of quality standards; the program management and the educational effectiveness.
\end{abstract}

Keywords: Quality, academic programs, NARS, Program Accreditation

\section{Introduction}

Educational institutes play an essential role in development. They support global development strategies with the necessary highly qualified manpower and research. The success of educational institutes in achieving this role necessitates for them to have a strategic plan supported by a mechanism for monitoring, controlling and adjusting it. These institutions are comprised of academic departments (AD). The success of these institutions depends on the performance of AD's in achieving their objectives. An essential component of the mechanism is a set of performance measures that are used to assess the organization performance and its ability to achieve set targets (Al-Turki and Duffuaa, 2003).

Recently, the number of tourism and hotels AD's has raised rapidly around the world. Egypt has experienced considerable growth in the number of such programs since 1975. In this year, the Higher Institute of Tourism and the Higher Institute of Hospitality integrated together to be one educational body known until today as the "Faculty of Tourism and Hotel Management" - Helwan University which is believed to be the first faculty in the Middle East. Parallel to this, the pre-established hospitality training center was altered to be a two-year technical institution open for applicants who have a high school degree and are looking forward to having a technical diploma in hospitality and tourism (Abou Taleb, 2009).

Since that time, the Supreme Council of Universities (SCU) approved the establishment of a number of tourism and hotel management faculties all over Egypt. These faculties are displayed in (table 1). In addition, about nineteen private tourism higher institutes have been evolved and three private universities have established specific departments and/or faculties for teaching hospitality; two in 6th October governorate and one in Alexandria governorates (NAQAAE, 2009).All these faculties and institutes offer three academic programs for the bachelor degree: (1) tourism studies, (2) hotel management, and (3) tourism guidance.

Meanwhile, with the increase in number of academic programs, quality of education associated problems have always been a major issue (Horng, Teng, Lee, \& Liu,2006). As Robbins (2005) points out, society has high expectations of higher education (HE). Hence, educational evaluation/accreditation has become a significant quality assessment approach for tourism and hotels academic programs in order to remain strong and competitive (Bosselman, 1996). 
Table (1): Public faculty of tourism and hotels in Egypt.

\begin{tabular}{|c|c|c|}
\hline $\mathbf{N}$ & University & Opening Year \\
\hline 1 & Helwan & 1975 \\
\hline 2 & Alexandria & 1983 \\
\hline 3 & Fayoum & 1994 \\
\hline 4 & Suez Canal & 1995 \\
\hline 5 & Monofeia & 1997 \\
\hline 6 & Menia & 1998 \\
\hline 7 & Mansoura & 2006 \\
\hline 8 & South Valley & 2008 \\
\hline
\end{tabular}

Source: (NAQAAE, 2009)

The National Authority for Quality Assurance and Accreditation of Education NAQAAE was founded in Egypt with the issuing of law no. 82, year 2006 and the presidential decree no. 25, year 2007 stating the executive bylaws. It comprises several sectors including the Higher Education sector that is concerned with quality assurance in Higher Education institutions which embrace faculties, academies, in addition to higher, middle institutes and technological faculties. There are Three Types of Accreditation Schemes adopted by NAQAAE as follows: (1) institutional accreditation (2) program accreditation, and (3) university accreditation (NAQAAE, 2009). Academic departments are building blocks of educational institutions. They can be thought of as a unit with multiple inputs and outputs. The process of converting these inputs to outputs is complex in nature and also the outputs are hard to measure. Therefore, measuring the performance of academic departments is a challenging problem(Al-Turki \& Duffuaa, 2003).

Also, a major challenge for HE is to develop a valid instrument that identifies dimensions and indicators in order to measure the quality of education (Rao, Solis, \& Raghunathan, 1999). The need to evaluate tourism and hotels Programs accurately has become ever more important in Egypt and in the rest of the world. The complexity of HE and its multidimensional nature makes it very difficult to evaluate and measure, so there has been little empirical investigation of educational quality (Winn \& Cameron, 1998). Previous research has investigated how total quality management (TQM), for example, the Malcolm Baldrige National Quality Award (MBNQA), is applied in HE (Badri et al., 2006). However, it seems there is a need to modify TQM dimensions to meet the needs of educational programs (Mizikaci, 2006). In addition, traditional education evaluation models, such as the context-input-processproduct (CIPP) model by Stufflebeam (2000), need to be refined for program-specific measurement of tourism and hotels programs and to respond to the trends in TQM usage in HE. Furthermore, a new quality model for HE might use new perspectives which integrate the philosophy of quality management and the theory of education research in order to adapt to the modern HE context (Srikanthan \& Dalrymple, 2007). When considering the integration of TQM and CIPP perspectives, it is important that both internal and external evaluation employ a theoretically and empirically validated instrument to measure the quality of education (Horng ,Teng and Baum,2009).

Self-assessment is a critical aspect of quality assurance systems in HE (Harvey, 2004). The faculty, as internal stakeholder in tourism and hotels programs, should be able to assess the quality of their own programs. Faculty members may also act as peer-reviewers, based on the standards and evidence provided. This study, then, used the faculty members of tourist studies and hotel studies departments to assess the quality of their own academic departments using an instrument for measuring the quality of tourism and hotels programs. From a measurement perspective, faculty members are familiar with the programs they work on and are capable of assessing their quality in order to verify the instrument. Academics are also very aware of the dimensions of quality in HE. However, their views as stakeholders have been largely neglected, while the views of other stakeholders such as students and administrative staff have often been investigated (e.g. Pereda, Airey, \& Bennett, 2007; Badri et al., 2006). It is therefore meaningful to investigate academic views on the quality of their own academic departments since "the HE institutions themselves need to be able to measure, monitor, confirm and enhance their academic standards" (Robbins, 2005, p. 452).

The employed instrument was adopted from the standards for program accreditation put forward by NAQAA. These standards take into consideration the special characteristics of academic departments and include the program management and the educational effectiveness. 


\section{Literature Review}

\section{The Concept of Quality in Higher Education}

The word "quality" has been deduced from the Latin word Qualis, meaning, "what kind of". With a broad assortment of meanings and connotations attached to it, quality is a difficult and elusive term to define (Pfeffer and Coote, 1991). While quality is difficult to define, its importance is universally appreciated (Nichols, 2002). The word means different things to different people. It has, therefore, been defined with different perspectives and orientations, according to the person, the measures applied and the context within which it is viewed. With this wide range of definitions, there seems to be no consensus definition - but they all deal either with the product/services or the services producing these products/services. From the perspective of the consumers or users, the product or servicebased definition is more useful. From the perspective of the organization providing goods/services, which is a perspective relevant to TQM, the process-perspective is more useful. Horng, et al.,(2009) defines quality in Higher Education as that judged by an institution's ability to produce evidence to support its educational claims.

There are widely different conceptualizations of quality in education (Harvey, 1994). However, these can be grouped into five discrete but interrelated ways of thinking about quality (Sahney, Banwet, \& Karunes, 2004). Quality can be viewed as exceptional, as perfection (or consistency), as fitness for purpose, as value for money and as transformative (Sahney, et al., 2004).

Moreover, quality in colleges and universities can be viewed from three perspectives. One of these perspectives assumes that by definition quality is in limited supply - a competitive affair in which there is a few truly excellent institutions. A second perspective assumes that quality should be present in each and every institution according to its mission and goals. A third perspective assumes that quality is to be found not in resources and reputations but in results, in the "value added" by the institution. Higher education has fashioned several approaches to quality assurance that include the following traditional instruments: (1) accreditation: the test of mission and goal achievement; (2) rankings and ratings: the test of reputation; and (3) program reviews: the test of peer evaluation(Bogue, 1998).

\section{Different Approaches to Assess Quality in Higher Education}

Although previous evaluation/accreditation systems have developed a set of criteria to assess the quality of education, the measures used are often ad hoc and do not conform to systematic procedures for construct development (Horng et al., 2009). It would be more convincing to refine them into a new validated instrument in order to identify the quality dimensions and confirm the value attached to each dimension (Sahney et al., 2004). Quality measurement is significant in offering significant and decisive information pertaining to the assessed provision of HE. Despite the challenges connected with the complex nature of education quality, clear definition of the dimensions of HE quality is essential to perform appropriate quality measurement for HE. Numerous studies have attempted to identify different sets of dimensions by adopting different approaches to measure HE quality. These studies have been categorized into four different approaches based on the theoretical perspectives they apply to HE institutions: CIPP, TQM, SERVQUAL, and the combined approach (Table 2)

\section{Nature and Characteristics of Academic Departments}

Academic departments are service organizations and usually organized within educational institutes to provide education, conduct research and offer community services. Within the institutions, academic departments have a semi-antonymous status. In higher educational institutes, (universities and colleges), each department is chaired by a faculty member, who acts as a coordinator in managing the department activities. The responsibilities in academic departments are highly decentralized(Al-Turki \& Duffuaa, 2003). 
Table (2): Approaches to measure quality in Higher Education (Horng \& Teng, 2011)

\begin{tabular}{|c|c|c|c|}
\hline Approach & Theme & Dimensions/Criteria & Author(s) \\
\hline CIPP Accreditation & $\begin{array}{l}\text { Accreditation model for Hospitality } \\
\text { programmes }\end{array}$ & $\begin{array}{l}\text { 1. The objectives } \\
\text { 2. People } \\
\text { 3. Resources } \\
\text { 4. Processes }\end{array}$ & Heiman \& Sneed (1996) \\
\hline CIPP & $\begin{array}{c}\text { Programme performance } \\
\text { measurement }\end{array}$ & $\begin{array}{l}\text { 1. Input indicators } \\
\text { 2. Process indicators } \\
\text { 3. Outcome indicators }\end{array}$ & $\begin{array}{l}\text { Al-Turki \& Duffuaa } \\
\text { (2003) }\end{array}$ \\
\hline CIPP & $\begin{array}{l}\text { Quality of Hospitality management } \\
\text { programmes }\end{array}$ & $\begin{array}{l}\text { 1. Students/Graduates } \\
\text { 2. Industry support } \\
\text { 3. Faculty } \\
\text { 4. Facilities } \\
\text { 5. Curriculum } \\
\text { 6. Research }\end{array}$ & Assante et al. (2007) \\
\hline TQM(MBNQA) & Quality of HE institutions & $\begin{array}{l}\text { 1. Leadership } \\
\text { 2. Customer centre and satisfaction } \\
\text { 3. Strategic quality planning } \\
\text { 4. Human resource } \\
\text { development and management } \\
\text { 5. Quality process management } \\
\text { 6. Quality information analyses } \\
\text { 7. The outcomes of quality and operation }\end{array}$ & $\begin{array}{l}\text { Winn \& Cameron } \\
\text { (1998) }\end{array}$ \\
\hline TQM (MBNQA) & Quality of HE institutions & $\begin{array}{l}\text { 1. Leadership } \\
\text { 2. Strategic development } \\
\text { 3. Stakeholder and market focus } \\
\text { 4. Measurement, analysis and knowledge } \\
\text { management } \\
\text { 5. Workforce focus } \\
\text { 6. Process management } \\
\text { 7. The results of organization performance }\end{array}$ & $\begin{array}{l}\text { Badri, Selim, Alshare, } \\
\text { Grandon, Younis, \& } \\
\text { Absulla (2006) }\end{array}$ \\
\hline SERVQUAL & Quality of HE institutions & $\begin{array}{l}\text { 1. Tangibles } \\
\text { 2. Competence } \\
\text { 3. Attitude } \\
\text { 4. Content } \\
\text { 5. Delivery } \\
\text { 6. Reliability }\end{array}$ & $\begin{array}{l}\text { Owlia \& Aspinwall } \\
\text { (1996) }\end{array}$ \\
\hline SERVQUAL & $\begin{array}{l}\text { Service quality of the Business } \\
\text { School }\end{array}$ & $\begin{array}{l}\text { 1. Contact personnel } \\
\text { 2. Physical evidence } \\
\text { 3. Reputation } \\
\text { 4. Responsiveness } \\
\text { 5. Facilities accessibility } \\
\text { 6. Curriculum }\end{array}$ & Sohail \& Shaikh (2004) \\
\hline SERVQUAL & Quality of HE institutions & $\begin{array}{l}\text { 1. Non-academic dimension } \\
\text { 2. Academic dimension } \\
\text { 3. Reliability } \\
\text { 4. Empathy }\end{array}$ & Abdullah (2006) \\
\hline $\begin{array}{c}\text { Combined (CIPP } \\
\text { \&TQM) }\end{array}$ & $\begin{array}{l}\text { Quality of culinary } \\
\text { arts programmes }\end{array}$ & $\begin{array}{l}\text { 1. Facilities } \\
\text { 2. Faculty } \\
\text { 3. Learning opportunities } \\
\text { 4. Outcomes } \\
\text { 5. Organization and administration } \\
\text { 6. Student services }\end{array}$ & $\begin{array}{l}\text { Hertzman \& Stefanelli } \\
\text { (2007) }\end{array}$ \\
\hline $\begin{array}{c}\text { Combined (CIPP } \\
\text { \&TQM) }\end{array}$ & $\begin{array}{l}\text { Quality of hospitality, } \\
\text { tourism and leisure programmes }\end{array}$ & $\begin{array}{l}\text { 1. Strategic planning } \\
\text { 2. Curriculum and instruction } \\
\text { 3. Faculty } \\
\text { 4. Resources } \\
\text { 5. Student achievements } \\
\text { 6. Administrative management }\end{array}$ & Horng et al. (2009) \\
\hline
\end{tabular}


Typical objectives of academic departments include: prepare highly qualified graduates (Bachelor. or Diploma) in the discipline of the department; prepare graduates for lifelong learning experience, prepare graduates who can communicate effectively and function well within teamwork environment; prepare graduates (Master and Doctor of Philosophy) who can conduct research at the frontier of their discipline; extend the knowledge base in their disciplines to meet society needs; and provide continuous professional development for their graduate through continuous education, workshops and seminars(Al-Turki \& Duffuaa, 2003). To achieve the above objectives, academic departments have several inputs and processes that need to be available, monitored and continuously improved. The major inputs to an academic department include: highly qualified, motivated and committed faculty members; talented students with adequate background for the field of study; adequate support staff; well-equipped laboratories and computing facilities for certain disciplines; facilities and library resources; adequate procedures and standards; programs, curriculum, courses, schedules; financial resources and support services (canteen, recreation, food, transportation etc.(Mizikaci, 2006)

According to (Al-Turki \& Duffuaa, 2003) the delivery of service in an academic department requires certain processes that are critical for achieving department's objectives. These processes include: teaching processes, managerial processes, research supervision and support processes, students support processes and quality control processes. Moreover,(Mizikaci, 2006) added that the transformation process should include the following: design (courses, programs, schedules, inputs, class size); delivery (methods to deliver course material to the students); measurement of the outputs (number and frequency of quizzes, assignments and examinations); and evaluation of the program, the courses and the professors (student surveys, alumni, parents, employers).Mizikaci (2006) identified the outputs of an academic department as follows: academic achievement (success rates, skill development, competency); graduation, dropout, failure; post-graduation (pass rates on professional examinations, additional education, e.g. success rates in getting admission in graduate schools); and employment achievements (employer satisfaction) and Al-Turki \& Duffuaa (2003) added basic and applied research and services to society such as training and workshops as an additional output. Adequate measures of performance are required to assess whether academic departments meet their set objectives in order to initiate improvements. In the past, measuring the performance of academic department has received little attention compared to other industries. Possible reasons include: the functions of academic departments within an organization, has complex relationships with other functions and the outputs of the academic departments are hard to measure(Al-Turki \& Duffuaa, 2003).

\section{Research Methodology}

Faculty of Tourism and hotels, University of Sadat City, was used as a case study for this study. The research aimed to measure the quality of two Academic Departments; Tourism and Hotel Studies. In line with this aim, a key feature of the work was its concern to encourage ADs to conduct self-assessment and examine the gaps that need to be filled before applying for accreditation.

\section{Measure}

The present study adopted two main standards for Program Accreditation put forward by NAQAAE ; (1) program management which comprises three sub items ; mission and objectives, leadership and financial \& physical resources and (2) educational effectiveness which comprises six sub items; program structure, teaching and learning, academic staff, assessment of learning outcomes, program development \& enhancement, and indicators of success

\section{Participants and Data Collection Methods}

A questionnaire composed of 107 indicators was designed to assess the quality of, tourism and hotels ADs. The questionnaire used a Likert scale, ranging from 1 (strongly not covered) to 5 (strongly covered). The participants in this study were the academic staff of tourism and hotels ADs to examine their views about the availability of quality standards in their departments. The questionnaire form was distributed to fifteen belongs to the tourism academic department and fourteen belongs to the hotel studies department with a total of twenty nine academic staff. The questionnaire was piloted prior to embarking on the formal data collection phase. The questionnaire employed was divided into three main parts. The first one aimed to obtain demographic data of the respondents, the second part included (31) attributes to measure the effectiveness of program management, while the third and last one included (76) attributes which were considered as indicators of Educational Effectiveness. A total of twenty seven completed questionnaires were received only two of these were invalid because of incomplete responses, leaving twenty five valid questionnaires yielding a valid response rate of $(86) \%$. 


\section{Procedure and Data Analysis}

In the first examination of the data, a reliability analysis was performed for measuring the reliability of the items measuring quality in higher education in order to know to what extent these items have an internal consistency. Cronbach's alpha is used and employed here for that reason. The generally agreed upon lower limit for Cronbach's alpha is 0.70 (Nunnaly, 1978). The results of the reliability analysis are presented in Table (3). As the table shows, the reliability analysis gave alpha coefficients exceeding (.70), for all the study constructs which are regarded as acceptable reliability coefficients and a good indication of construct reliability, then descriptive statistics which include frequency distributions and cross-tabulations were computed and used to summarize data. The collected data have been classified and tabulated to be thoroughly analyzed using Statistical Package for Social Science (SPSS) version 18.0. The mean and standard deviation have been calculated to classify the sets and determine how homogenous or discrepant (inconsistent) the sample is, regarding all research variables. A t-test was performed to identify the significant differences between the two academic departments with regard to how they fit the quality standards for accreditation.

Table (3): Reliability Statistics

\begin{tabular}{|c|l|c|}
\hline $\mathbf{N}$ & \multicolumn{1}{|c|}{ Construct } & Cronbach's Alpha \\
\hline $\mathbf{1}$ & Program mission and goals & $\mathbf{8 3 2}$ \\
\hline $\mathbf{2}$ & Program Leadership and organization & .725 \\
\hline $\mathbf{3}$ & Financial resources and enhancing physical facilities & .887 \\
\hline $\mathbf{4}$ & Program academic standards & .901 \\
\hline $\mathbf{5}$ & Students & .754 \\
\hline $\mathbf{6}$ & Faculty staff members & .814 \\
\hline $\mathbf{7}$ & Instruction and learning & .769 \\
\hline $\mathbf{8}$ & Evaluating the learning outcomes & .921 \\
\hline $\mathbf{9}$ & Improvement & .768 \\
\hline
\end{tabular}

\section{Results and Discussion: Demographic profile of respondents}

The demographic profile of respondents is summarized in Table (4) 12 respondents (48\%) were from the hotel studies $\mathrm{AD}$, whereas 13 respondents (52\%) were from the tourism studies $\mathrm{AD}$. In terms of academic rank, the largest group of tourism $\mathrm{AD}$ respondents in the distribution was comprised of instructors $(62 \%)$; followed by associate professors $(23 \%)$ and professors (15\%). Moreover, the largest group of hotel studies AD respondents was instructors $(66 \%)$ followed by associate professors $(17 \%)$ and professors $(17 \%)$. The means and standard deviations for sub-dimensions across both ADs are given in Table 4. Also, the experience of the largest group of hotel studies AD respondents was from 1 to five years $(91.6 \%)$ followed by the group whose experience range from eleven to fifteen $(8.4 \%)$. On the other hand, the experience of the largest group of tourism studies AD respondents was from 1 to five years (92\%) followed by the group whose experience range from eleven to fifteen $(8 \%)$.

Table (4): Profile of Respondents

\begin{tabular}{|l|c|c|c|c|}
\hline \multirow{2}{*}{ Demographic variables } & \multicolumn{2}{|c|}{$\begin{array}{c}\text { Tourism Department } \\
(\boldsymbol{n}=\mathbf{1 3 )}\end{array}$} & \multicolumn{2}{c|}{$\begin{array}{c}\text { Hotel Studies } \\
\text { Department (n=12) }\end{array}$} \\
\cline { 2 - 5 } & $\boldsymbol{n}$ & $\boldsymbol{\%}$ & $\boldsymbol{n}$ & $\%$ \\
\hline Academic rank & & & 2 & $17 \%$ \\
\hline Professor & 2 & $15 \%$ & 2 & $17 \%$ \\
\hline Associate professor & 3 & $23 \%$ & 8 & $66 \%$ \\
\hline Instructor & 8 & $62 \%$ & & \\
\hline $\begin{array}{l}\text { Employed years in current } \\
\text { department }\end{array}$ & & & 11 & 91.6 \\
\hline 1-5 years & 12 & $92 \%$ & 0 & $0 \%$ \\
\hline 6-10 years & 0 & $0 \%$ & 1 & $8.4 \%$ \\
\hline 11-15 years & 1 & $8 \%$ & 0 & $0 \%$ \\
\hline More than 15 years & 0 & $0 \%$ & & \\
\hline
\end{tabular}




\section{Results of the program management dimension}

Regarding the program management dimension, as displayed in table (5), results revealed that both departments have not yet put forward a mission. As stated by (Horng et al., 2009) the mission statement ultimately attempt to answer the question of what does an institution or organization seek to achieve and consider one of the important tools to manage and measure performance. Therefore, the absence of the department's mission will lead to a department unable to define to where it goes and an unclear vision. Although the two departments adopted certified goals, the hotel studies AD rather effectively disseminated such goals inside and outside the faculty and considered the labor market requirements in outlining them (Mean 3.0) compared with the tourism studies AD (Mean 2.1). However both ADs still need to effectively communicate with labor market to identify requirements that should exist in their graduates and consider these needs in putting forward their goals.

With respect to the program leadership and organization, both ADs have failed to score high in the most of these sub-dimension indicators. The only exception was found in two indicators. Firstly, the two departments assigned their own program coordinators. However, they do not set clear and certified criteria for their selection. Secondly, the program administrative body members were found to be sufficient and efficient in the two ADs. Results, also, referred to a serious shortage in updating the program data which has been clearly noticed in the obsolete database being uploaded on the faculty website. This condition could be enhanced if the portal establishment project for universities and technical universities-one of the information \& communication technology projects (ICTP) - was effectively integrated with the management information system of ADs. (Nichols, 2002)

Both departments were found to suffer from the lack of sufficient annual funding to achieve the program mission and goals. This insufficient funding makes it difficult for departments to subscribe in specialized electronic journals and avail the internet service for the students of the program. The funding has always been a problematic issue facing ADs. However, departments can gain funds through applying for the various competitive projects frequently launched by the Ministry of Higher Education. On the other hand, both departments rather managed to introduce classrooms sufficient for the program requirements appropriate for the instructional process. They also have labs and technical facilities appropriate for the nature of the program and their libraries have fairly Arabic and foreign references and periodicals relevant to the program.

Table (5): Program Management Attributes

\begin{tabular}{|c|c|c|c|c|c|}
\hline \multicolumn{2}{|r|}{$\begin{array}{c}\text { Dimension(1) Program Management } \\
\text { Sub-dimensions }\end{array}$} & \multicolumn{2}{|c|}{$\begin{array}{c}\text { Tourism } \\
\text { Department } \\
(\mathrm{n}=) \quad\end{array}$} & \multicolumn{2}{|c|}{$\begin{array}{c}\text { Hotel Studies } \\
\text { Department } \\
(\mathrm{n}=\quad)\end{array}$} \\
\hline & & $M$ & SD & $M$ & SD \\
\hline \multicolumn{2}{|r|}{ 1- Program Mission and Goals } & 1.76 & 1.16 & 1.58 & 1.05 \\
\hline 1 & There is a mission for the program & 1 & .000 & 1 & .000 \\
\hline 2 & The program mission consistent with the certified mission of the faculty & 1 & .000 & 1 & .000 \\
\hline 3 & The mission is certified & 1 & .000 & 1 & .000 \\
\hline 4 & $\begin{array}{l}\text { The mission is disseminated via various means inside and outside the } \\
\text { faculty. }\end{array}$ & 1 & .000 & 1 & .000 \\
\hline 5 & There are definite official mechanisms of the mission regular review & 1 & .000 & 1 & .000 \\
\hline 6 & The program goals are certified & 4.0 & .000 & 4.0 & .000 \\
\hline 7 & The goals are disseminated inside and outside the faculty. & 3.0 & .000 & 2.1 & .000 \\
\hline 8 & The program is consistency with labor market requirements & 2.1 & 0.065 & 1.6 & 0.23 \\
\hline \multicolumn{2}{|r|}{ 2- Program Leadership and Organization } & $\begin{array}{c}1.516 \\
7\end{array}$ & 1.104 & 1.4917 & $\begin{array}{c}1.10 \\
2\end{array}$ \\
\hline 9 & There are criteria for selecting the program coordinator & 3.6 & .785 & 3.3 & .543 \\
\hline 10 & Those criteria are certified and announced & 1.5 & .321 & 1.3 & .432 \\
\hline 11 & $\begin{array}{l}\text { There is a certified system for evaluating the academic leadership } \\
\text { performance }\end{array}$ & 1.0 & .000 & 1.0 & .000 \\
\hline 12 & There is an organizational structure for managing the program & 1.0 & .000 & 1.0 & .000 \\
\hline 13 & This organizational structure is certified and announced & 1.0 & .000 & 1.0 & .000 \\
\hline 14 & The organizational structure comprise clear authority relationships & 1.0 & .000 & 1.0 & .000 \\
\hline 15 & The program administrative body members are sufficient and efficient & 4.1 & .321 & 4.3 & 1.23 \\
\hline
\end{tabular}




\begin{tabular}{|l|l|c|c|c|c|}
\hline 16 & There is a data base for the program & $\mathbf{1 . 0}$ & $\mathbf{. 0 0 0}$ & $\mathbf{1 . 0}$ & $\mathbf{. 0 0 0}$ \\
\hline 17 & The data base is being updated & $\mathbf{1 . 0}$ & $\mathbf{. 0 0 0}$ & $\mathbf{1 . 0}$ & $\mathbf{. 0 0 0}$ \\
\hline 18 & All the program information is accessible on the institution website & $\mathbf{1 . 0}$ & $\mathbf{. 0 0 0}$ & $\mathbf{1 . 0}$ & $\mathbf{. 0 0}$ \\
\hline 19 & There is a system for documents storage and retrieval & $\mathbf{1 . 0}$ & $\mathbf{. 0 0 0}$ & $\mathbf{1 . 0}$ & $\mathbf{. 0 0 0}$ \\
\hline 20 & This system support the program in fulfilling its goals & $\mathbf{1 . 0}$ & $\mathbf{. 0 0 0}$ & $\mathbf{1 . 0}$ & $\mathbf{. 0 0 0}$ \\
\hline \multicolumn{2}{|c|}{$\mathbf{3 - F i n a n c i a l}$ Resources and Enhancing Physical Facilities } & $\mathbf{2 . 5 0}$ & $\mathbf{1 . 1 2}$ & $\mathbf{2 . 6 1}$ & $\mathbf{1 . 1 3}$ \\
\hline 21 & $\begin{array}{l}\text { There is an annual funding sufficient to achieve the program mission and } \\
\text { goals }\end{array}$ & $\mathbf{1 . 0}$ & $\mathbf{. 0 0 0}$ & $\mathbf{1 . 2}$ & $\mathbf{. 5 2}$ \\
\hline 22 & Classrooms are sufficient for the program requirements & $\mathbf{3 . 4}$ & $\mathbf{0 . 1 1}$ & $\mathbf{4 . 0}$ & $\mathbf{0 . 1 8}$ \\
\hline 23 & Classrooms are appropriate for the instructional process & $\mathbf{3 . 1}$ & $\mathbf{1 . 2 1}$ & $\mathbf{2 . 9}$ & $\mathbf{0 . 6 5}$ \\
\hline 24 & $\begin{array}{l}\text { The labs and technical facilities are sufficient for achieving the program } \\
\text { goals }\end{array}$ & $\mathbf{2 . 8}$ & $\mathbf{1 . 6 2}$ & $\mathbf{2 . 9}$ & $\mathbf{1 . 6 9}$ \\
\hline 25 & $\begin{array}{l}\text { The labs and technical facilities are appropriate for the nature of the } \\
\text { program }\end{array}$ & $\mathbf{3 . 1}$ & $\mathbf{1 . 3 2}$ & $\mathbf{3 . 6}$ & $\mathbf{1 . 1 1}$ \\
\hline 26 & $\begin{array}{l}\text { There are appropriate means to ensure security and safety (guiding } \\
\text { signs/ fire extinguishers ) }\end{array}$ & $\mathbf{1 . 6}$ & $\mathbf{0 . 8 7}$ & $\mathbf{2 . 0}$ & $\mathbf{1 . 0 9}$ \\
\hline 27 & $\begin{array}{l}\text { There is a healthy climate in the buildings and labs allocated for the } \\
\text { Program (ventilation/ natural lighting/ cleanliness/ etc.) }\end{array}$ & $\mathbf{3 . 1}$ & $\mathbf{0 . 3 2}$ & $\mathbf{2 . 9}$ & $\mathbf{0 . 3 2}$ \\
\hline 28 & $\begin{array}{l}\text { The information technology used in the library is accessible to all the } \\
\text { target groups (Internet/ subscription in specialized electronic journals. }\end{array}$ & $\mathbf{1 . 0}$ & $\mathbf{0 . 0 0 0}$ & $\mathbf{1 . 0}$ & $\mathbf{0 . 0 0}$ \\
\hline 29 & $\begin{array}{l}\text { The Arabic and foreign references and periodicals relevant to the program } \\
\text { are available }\end{array}$ & $\mathbf{3 . 4}$ & $\mathbf{1 . 2 2}$ & $\mathbf{3 . 5}$ & $\mathbf{0 . 5 4}$ \\
\hline 30 & These references and periodicals are up-to-date & $\mathbf{4 . 0}$ & $\mathbf{1 . 3 2}$ & $\mathbf{3 . 8}$ & $\mathbf{0 . 9 8}$ \\
\hline 31 & $\begin{array}{l}\text { The internet service is available for the students of the program } \\
\text { The overall mean an standard deviation }\end{array}$ & $\mathbf{1 . 0}$ & $\mathbf{0 . 0 0 0}$ & $\mathbf{1 . 0}$ & $\mathbf{0 . 0 0}$ \\
\hline
\end{tabular}

\section{Results of the Educational Effectiveness Dimension}

Regarding the educational effectiveness dimension, results, as displayed in table (6), revealed that both programs paid a great attention to the program academic standards. They adopted the National Academic Reference Standards (NARS) which describes the minimum requirements to accomplish a certain program. It includes graduate attributes and characterizes knowledge and understanding, as well as professional, intellectual and transferable skills. Both departments were concerned with taking into consideration the graduate's attributes which are identified according to the real needs of the community and frequently review these attributes in terms of the societal changes. The two departments also started to adopt the national standards aligned with the goals for their programs. Official measures are used in the two departments to ensure commitment of applying these academic standards. Moreover, the results revealed that there is a certified description of each one of the two programs accompanied with the knowledge and skills matrix for the program and the intended learning outcomes of the program are fairly aligned with the adopted academic standards.

Most respondents believe that the courses description achieves the basic knowledge and skills in terms of the program academic standards and consider that the contents of these courses are aligned with their intended learning outcomes. The students' evaluations are being analyzed objectively and the program structure and contents are regularly reviewed by external specialized reviewers. The results of the review are exploited to a lesser degree in improving and updating the program. These achievements may due to the fact that the investigated departments have already gone through the QAAP project which qualified them to build up an internal quality system.

On the other hand, some missing indicators are found. For example, the community stakeholders are not effectively participating in the program design. 
Table (6): Educational Effectiveness Sub-dimensions mean

\begin{tabular}{|c|c|c|c|c|c|}
\hline \multirow{2}{*}{\multicolumn{2}{|c|}{$\begin{array}{l}\text { Dimension(2) Educational Effectiveness } \\
\text { Sub-dimensions }\end{array}$}} & \multicolumn{2}{|c|}{$\begin{array}{c}\text { Tourism } \\
\text { Department } \\
(\mathrm{n}=)\end{array}$} & \multicolumn{2}{|c|}{$\begin{array}{l}\text { Hotel } \\
\text { Studies } \\
\text { Department } \\
(\mathrm{n}=\quad)\end{array}$} \\
\hline & & M & SD & M & SD \\
\hline \multicolumn{2}{|r|}{ 1-Program Academic Standards } & 3.3 & 0.92 & 3.2 & 0.90 \\
\hline 1 & $\begin{array}{l}\text { The graduate's attributes are identified according to the real needs } \\
\text { of the community }\end{array}$ & 3.2 & 0.18 & 3.0 & 1.06 \\
\hline 2 & $\begin{array}{l}\text { The graduate's attributes are reviewed in terms of the societal } \\
\text { changes }\end{array}$ & 2.4 & 0.08 & 3.4 & 1.05 \\
\hline 3 & $\begin{array}{l}\text { The review results have been used in updating the graduate's } \\
\text { attributes }\end{array}$ & 1.6 & 0.08 & 1.0 & 1.08 \\
\hline 4 & The faculty adopts the national standards for the program & 4.6 & 0.07 & 3.6 & 1.21 \\
\hline 5 & $\begin{array}{l}\text { The standards are aligned with the mission and goals of the } \\
\text { program }\end{array}$ & 3.9 & 0.27 & 3.5 & 1.09 \\
\hline 6 & The standards are disseminated among all stakeholders & 2.1 & 0.08 & 2.0 & 0.80 \\
\hline 7 & $\begin{array}{l}\text { There are official measures used to ensure commitment of } \\
\text { applying the academic standards in the program }\end{array}$ & 4.0 & 0.86 & 3.7 & 1.90 \\
\hline 8 & The standards are adhered to in the program & 4.2 & 0.96 & 4.1 & 1.60 \\
\hline 9 & There is a certified description of the program & 4.1 & 0.64 & 4.0 & 1.86 \\
\hline 10 & There is a knowledge and skills matrix for the program & 4.3 & 0.84 & 4.4 & 1.27 \\
\hline 11 & $\begin{array}{l}\text { The intended learning outcomes of the program are aligned with the } \\
\text { adopted academic standards }\end{array}$ & 3.2 & 0.27 & 3.3 & 0.90 \\
\hline 12 & $\begin{array}{l}\text { The community stakeholders have participated in designing the } \\
\text { program }\end{array}$ & 2.2 & 0.90 & 2.0 & 0.70 \\
\hline 13 & There is a certified description of the instructional courses & 2.1 & 0.00 & 2.1 & 1.17 \\
\hline 14 & $\begin{array}{l}\text { The description includes a knowledge and skills matrix for each } \\
\text { course }\end{array}$ & 3.3 & 0.00 & 3.9 & 1.40 \\
\hline 15 & $\begin{array}{l}\text { The courses description achieves the basic knowledge and skills in } \\
\text { terms of the program academic standards }\end{array}$ & 3.5 & 0.23 & 3.4 & 0.75 \\
\hline 16 & $\begin{array}{l}\text { The contents of the courses are aligned with the intended learning } \\
\text { outcomes of these courses }\end{array}$ & 4.3 & 0.13 & 3.9 & 1.17 \\
\hline 17 & $\begin{array}{l}\text { The students' reactions to the instructional courses are assessed by } \\
\text { the end of each semester }\end{array}$ & 4.4 & 0.11 & 4.2 & 0.23 \\
\hline 18 & The results are being analyzed objectively & 3.4 & 0.22 & 3.3 & 1.02 \\
\hline 19 & The program is being reviewed regularly & 2.4 & 0.01 & 2.2 & 0.85 \\
\hline 20 & $\begin{array}{l}\text { The program structure and contents are reviewed by external } \\
\text { specialized reviewers }\end{array}$ & 3.4 & 0.23 & 3.5 & 1.06 \\
\hline 21 & $\begin{array}{l}\text { The results of the review are exploited in improving and updating } \\
\text { the program }\end{array}$ & 2.3 & 0.06 & 2.5 & 0.92 \\
\hline \multicolumn{2}{|r|}{ 2-Students } & 2.84 & 1.53 & 2.88 & 1.51 \\
\hline 22 & $\begin{array}{l}\text { There are announced certified criteria and measures for program } \\
\text { admission }\end{array}$ & 3.2 & 0.07 & 3.1 & 0.49 \\
\hline 23 & The admitted students' lists are announced & 5 & 0.41 & 5 & 1.53 \\
\hline 24 & $\begin{array}{l}\text { There are criteria and measures for students' transfer from and to } \\
\text { the program }\end{array}$ & 3.4 & 0.51 & 3.2 & 1.55 \\
\hline 25 & The policies and measures of admission and transfer are flexible & 1.2 & 0.12 & 1.3 & 1.85 \\
\hline 26 & $\begin{array}{l}\text { There is a system for submitting and examining students' } \\
\text { grievances }\end{array}$ & 5 & 0.15 & 5 & 1.68 \\
\hline 27 & This system is announced for the students & 5 & 0.08 & 5 & 0.85 \\
\hline 28 & $\begin{array}{l}\text { There is an academic advising system for the students enrolled in } \\
\text { the program }\end{array}$ & 4.0 & 0.05 & 4.4 & 0.23 \\
\hline
\end{tabular}




\begin{tabular}{|c|c|c|c|c|c|}
\hline 29 & $\begin{array}{l}\text { There is a certified system for assessing the effectiveness of } \\
\text { the academic advising. }\end{array}$ & 2.0 & 0.25 & 2.3 & 1.20 \\
\hline 30 & $\begin{array}{l}\text { This system is announced for the stakeholders ( students/ staff } \\
\text { members/ junior staff/ administrative divisions/ quality } \\
\text { management unit) }\end{array}$ & 2.2 & 1.22 & 2.1 & 1.22 \\
\hline 31 & $\begin{array}{l}\text { There are programs for supporting the academically distinguished } \\
\text { students }\end{array}$ & 1.2 & 1.39 & 1.1 & 0.18 \\
\hline 32 & $\begin{array}{l}\text { There are programs for supporting students with } \\
\text { learning difficulties. }\end{array}$ & 1.3 & 1.14 & 1.2 & 0.43 \\
\hline 33 & There are programs for supporting students with special needs. & 1.0 & 1.24 & 1.3 & 0.27 \\
\hline 34 & $\begin{array}{l}\text { There are physical facilities available for students with special } \\
\text { needs }\end{array}$ & 1.0 & 0.99 & 1.1 & 0.04 \\
\hline 35 & Students' satisfaction with the program is being assessed & 4.0 & 0.38 & 3.9 & 0.52 \\
\hline 36 & The results are exploited & 3.2 & 1.59 & 3.3 & 0.00 \\
\hline \multicolumn{2}{|r|}{ 3-Faculty Staff Members } & 2.7 & 1.20 & 2.9 & 1.08 \\
\hline 37 & $\begin{array}{l}\text { The number of senior and junior staff members is sufficient to meet } \\
\text { the requirements of the program instructional process }\end{array}$ & 4.2 & 0.25 & 4.1 & 0.58 \\
\hline 38 & $\begin{array}{l}\text { There are any measures taken to deal with the shortage or excess in } \\
\text { the number of senior and junior staff members }\end{array}$ & 4.5 & 1.22 & 4.2 & 0.35 \\
\hline 39 & $\begin{array}{l}\text { The academic specialty of the faculty staff members are appropriate } \\
\text { for the program courses }\end{array}$ & 4.2 & 1.39 & 4.3 & 0.54 \\
\hline 40 & $\begin{array}{l}\text { There are certified and stated criteria for selecting the faculty staff } \\
\text { members who are teaching in the program }\end{array}$ & 3.5 & 1.14 & 3.4 & 0.68 \\
\hline 41 & $\begin{array}{l}\text { The faculty staff members are interactive with the labour market } \\
\text { and community sectors }\end{array}$ & 2.1 & 1.24 & 2.6 & 1.41 \\
\hline 42 & $\begin{array}{l}\text { There are certified plans for developing the abilities and skills of } \\
\text { senior and junior staff members in recent learning and teaching } \\
\text { methods }\end{array}$ & 3.2 & 0.99 & 3.8 & 0.96 \\
\hline 43 & There are mechanisms for assessing the impact of the training & 2.1 & .38 & 2.4 & 0.83 \\
\hline 44 & $\begin{array}{l}\text { The motivation policy is implemented on the academic and } \\
\text { executive management of the program as well as the faculty senior } \\
\text { and junior staff members }\end{array}$ & 1.2 & 1.59 & 1.6 & 0.70 \\
\hline 45 & $\begin{array}{l}\text { There are mechanisms to activate the motivation and } \\
\text { accountability systems in the program }\end{array}$ & 1.4 & 1.40 & 1.5 & 0.39 \\
\hline 46 & $\begin{array}{l}\text { There are certified mechanisms for evaluating the performance of } \\
\text { senior and junior staff members }\end{array}$ & 1.0 & 1.62 & 1.3 & 0.00 \\
\hline 47 & Senior and junior staff members' satisfaction is being assessed & 2.2 & 1.23 & 2.7 & 0.863 \\
\hline 48 & The results of satisfaction assessment are exploited & 1.2 & 0.52 & 1.3 & 0.34 \\
\hline \multicolumn{2}{|r|}{ 4-Instruction and learning } & 2.5 & 0.75 & 2.4 & 0.88 \\
\hline 49 & $\begin{array}{l}\text { There are certified policies for instruction and learning aligned with } \\
\text { the nature of the program. }\end{array}$ & 2.1 & 1.44 & 2.1 & 0.92 \\
\hline 50 & $\begin{array}{l}\text { The instruction and learning policies are being reviewed regularly } \\
\text { in terms of exams results/ reactions of students, staff members and } \\
\text { stakeholders }\end{array}$ & 2.4 & 1.26 & 2.2 & 0.18 \\
\hline 51 & $\begin{array}{l}\text { The instruction and learning policies are being reviewed in terms of } \\
\text { recent trends in teaching and learning }\end{array}$ & 2.6 & 1.50 & 2.3 & 0.00 \\
\hline 52 & $\begin{array}{l}\text { The teaching methods involve specific techniques for developing } \\
\text { self-learning. }\end{array}$ & 2.3 & 1.77 & 2.2 & 0.34 \\
\hline 53 & Students are motivated for self-learning & 2.0 & 0.17 & 2.1 & 0.26 \\
\hline 54 & There is a certified plan for field experience & 1.9 & 1.12 & 1.6 & 0.22 \\
\hline 55 & There is a variety in the training bodies & 4.4 & 1.05 & 4.7 & 0.19 \\
\hline 56 & $\begin{array}{l}\text { There are certified mechanisms for evaluating the field experience } \\
\text { results }\end{array}$ & 2.3 & 1.22 & 2.2 & 0.09 \\
\hline 57 & The results are taken into account in the students' evaluation & 2.4 & 1.27 & 2.6 & 1.06 \\
\hline
\end{tabular}


Evaluating the Quality of Tourism and Hotels Academic Departments

\begin{tabular}{|c|c|c|c|c|c|}
\hline & process & & & & \\
\hline \multicolumn{2}{|r|}{ 5-Evaluating the Learning Outcomes } & 1.73 & 0.527 & 1.80 & 0.623 \\
\hline 58 & The exams results are used in the student's portfolio & 1.2 & 0.00 & 1.0 & 0.00 \\
\hline 59 & There is a system for evaluating the students' learning outcomes & 2.3 & 1.40 & 2.2 & 1.21 \\
\hline 60 & The system is certified and announced & 1.2 & 0.00 & 1.1 & 1.09 \\
\hline 61 & $\begin{array}{l}\text { The continuous assessment ways are used to measure the intended } \\
\text { learning outcomes }\end{array}$ & 1.3 & 0.66 & 1.2 & 0.30 \\
\hline 62 & The different types of tests address the intended learning outcomes & 2.3 & 1.46 & 2.2 & 0.90 \\
\hline 63 & There is a portfolio to follow-up the student's performance & 1.0 & 0.00 & 1.6 & 0.60 \\
\hline 64 & $\begin{array}{l}\text { The results of the intended learning outcomes evaluation system are } \\
\text { reviewed and analyzed }\end{array}$ & 2.3 & 0.11 & 2.6 & 0.86 \\
\hline 65 & The results are presented to the authorized boards & 2.1 & 0.00 & 2.4 & 1.27 \\
\hline 66 & This system is certified and announced to the students & 2.0 & 0.14 & 2.4 & 0.90 \\
\hline 67 & The stakeholders participate in the suggested modifications & 1.3 & 0.12 & 1.0 & 0.00 \\
\hline 68 & $\begin{array}{l}\text { The suggested modifications have contributed in consolidating the } \\
\text { program }\end{array}$ & 2.1 & 0.66 & 2.0 & 0.00 \\
\hline \multicolumn{2}{|r|}{ 6-Improvement } & 1.6 & 0.53 & 1.5 & 0.47 \\
\hline 69 & There is a plan for improving the program & 1.2 & 0.06 & 1.1 & 0.75 \\
\hline 70 & This plan is certified and announced & 1.0 & 0.05 & 1.2 & 0.06 \\
\hline 71 & External reviewer participated in developing the plan & 1.3 & 0.08 & 1.4 & 0.05 \\
\hline 72 & There are procedures for quality management in the program & 2.1 & 0.21 & 2.2 & 0.08 \\
\hline 73 & $\begin{array}{l}\text { The quality measures include review of the regular reports of the } \\
\text { study program and courses }\end{array}$ & 2.4 & 0.09 & 2.3 & 0.21 \\
\hline 74 & $\begin{array}{l}\text { There are awareness raising programs of the quality concepts and } \\
\text { elements in the program }\end{array}$ & 1.0 & 0.80 & 1.2 & 0.09 \\
\hline 75 & The evaluation of the quality level is conducted regularly & 1.8 & 0.90 & 1.3 & 0.10 \\
\hline 76 & The stakeholders' points of view and attitudes are explored & 1.9 & 0.60 & 1.4 & 0.00 \\
\hline & The overall mean and standard deviation & 1.96 & 1.03 & 2.01 & 1.06 \\
\hline
\end{tabular}

Concerning the students sub dimension, results revealed that there are announced certified criteria and measures for program admission and the admitted students' lists are announced. Results also indicated that there are criteria and measures for students' transfer from and to the program however, the policies and measures of admission and transfer need to be more flexible.

In addition, there is an announced for submitting and examining students' grievances. Although there is an academic advising system for the students enrolled in the program, most respondents see that there is no a certified rules for assessing the effectiveness of this system and reported that the system needs to be announced for the stakeholders (students/ staff members/ junior staff/ administrative divisions/ quality assurance unit). Both departments do not largely provide special programs supporting the following incidents: academically distinguished students, students with learning difficulties, and students with special needs. The results also revealed that 
students' satisfaction with the program is being assessed but there is no a clear policy of how to use this evaluation for the benefit of the educational effectiveness.

Moreover, results declared some positives aspects regarding the faculty staff members. For example, the number of senior and junior staff members is sufficient to meet the requirements of the program instructional process. This may due to the fact that there is a declared plan deals with the shortage or excess in the number of senior and junior staff members. The academic specialties of the faculty staff members are appropriate for the program courses. There are certified and stated criteria for selecting the faculty staff members who are teaching in each one of the two programs. There are also certified plans for developing the abilities and skills of senior and junior staff members in recent learning and teaching methods. However, the mechanisms for assessing the impact of such training programs is not clear cut and unmeasurable.

On the other hand, some negative aspects are stemmed from the respondents. For example, the two departments' staff members are not largely interactive with the labour market and community sectors; the motivation policy is not widely implemented on the academic and executive management of the program. There are no clear mechanisms to activate the motivation and accountability systems in the program. Also, there are no certified mechanisms for evaluating the performance of senior and junior staff members. Finally, there is no assessment for senior and junior staff members' satisfaction.

Regarding the instruction and learning dimension, it has been found that although there is a variety in the training bodies, there is no a certified plan for field experience in the two departments. Although the results of training are taken into account in the students' evaluation process, there are no clear certified mechanisms for evaluating the field experience results. Moreover, there are no certified policies for instruction and learning aligned with the nature of the program. The instruction and learning policies are neither being reviewed regularly in terms of exams results/ reactions of students, staff members and stakeholders nor are being reviewed in terms of recent trends in teaching and learning. Also, the teaching methods do not largely involve specific techniques for developing selflearning ad hence, students are not motivated for self-learning fairly enough. With respect to evaluating the learning outcomes dimension, there is no a clear and certified system for evaluating the students' learning outcomes. The continuous assessment ways are not largely used to measure the intended outcomes. The different types of tests do not properly address the intended learning outcomes (ILOs). Results also, indicated that there is no a portfolio to follow-up the student's performance and hence results are not used in the student's portfolio. The intended learning outcomes evaluation system is not effectively certified and announced to the students. Therefore, the results of that system are not largely reviewed, analysed and presented to the authorized boards of the two departments. Findings also revealed that the stakeholders do not effectively participate in the suggested modifications of the program ILOs. Thus, the contribution of stakeholders in consolidating the program appears to be not enough.

Regarding the improvement dimension, the two academic departments responded negatively to most of the dimension indicators. Respondents reported that there is no clear certified and announced a plan for improving the program and there is a weak participation from external reviewers in developing the plan of department improvement. There are some procedures for quality management in the program and quality measures. The quality measures to some extent include review of the regular reports of the study program and courses. Moreover, the awareness raising programs of the quality concepts and elements in the program are not quite enough and finally the evaluation of the quality level is not conducted on a regular basis. The means and standard deviations for sub-dimensions across both samples are given in Table 7. The total perceived quality mean scores for the hotel studies AD and tourism studies $\mathrm{AD}$ members are $2.31(\mathrm{SD}=1.128)$ and $2.28(\mathrm{SD}=1.38)$, respectively. The results of mean scores showed that $\mathrm{AD}$ members from both samples rated the overall quality of their program negatively, but the hotel studies AD members exhibited higher mean scores both in total and in different sub-dimensions of perceived program quality. Moreover, (t)-tests are conducted to evaluate whether the mean quality of tourism AD scores differ significantly from the mean quality of hotel AD scores. Table 7 illustrates results that indicate that the two AD don't differ significantly. 
Table (7): Results of the Two Academic Departments' Performance Measure

\begin{tabular}{|c|c|c|c|c|c|c|c|}
\hline & & & $\mathbf{N}$ & Mean & $\begin{array}{c}\text { Std. } \\
\text { Deviation }\end{array}$ & $\mathbf{t}$ & $\begin{array}{l}\text { Sig. (2- } \\
\text { tailed) }\end{array}$ \\
\hline \multirow{3}{*}{ 茵 } & \multirow{3}{*}{ 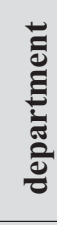 } & Program management & 31 & 1.94 & 1.17 & 8.874 & .000 \\
\hline & & $\begin{array}{l}\text { Educational } \\
\text { effectiveness }\end{array}$ & 76 & 1.96 & 1.03 & 20.308 & .000 \\
\hline & & Overall quality & 107 & 2.2879 & 1.3893 & 20.963 & .000 \\
\hline \multirow{3}{*}{$\frac{\infty}{\stackrel{0}{0}}$} & \multirow{3}{*}{ 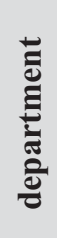 } & Program management & 31 & 1.96 & 1.19 & 8.768 & .000 \\
\hline & & $\begin{array}{l}\text { Educational } \\
\text { effectiveness }\end{array}$ & 76 & 2.01 & 1.06 & 20.642 & .000 \\
\hline & & Overall quality & 107 & 2.3103 & 1.1283 & 21.179 & .000 \\
\hline
\end{tabular}

\section{Conclusion}

The present study provides insights on the quality of academic departments and how it can be measured. Two academic departments of the faculty of Tourism and Hotels, University of Sadat City (hotel studies and tourism studies departments) are selected as a case study to in depth investigate how far they managed to achieve the quality standards. Two main standards for Program Accreditation put forward by NAQAAE; (1) Program management and (2) Educational Effectiveness which comprises 107 indicators were used to measure the extent to which the two ADs managed to meet the quality requirements. Results revealed that although a few areas of quality attributes are covered, there many other areas which are partially covered and others are fully not covered. The absence of published mission of academic departments, the lack of sufficient annual funding to fulfill their goals, and the unavailable up-to-date database of their activities are still missing areas and need to be given more effort to produce an effective program management. Results also revealed that both programs adopted the National Academic Reference Standards (NARS) for the bachelor degree and (ARS) for post graduates. But, both did not use external reference points with which the quality standards of programs can be compared. These results call the need for a more effective role of the quality assurance unit which undertakes the responsibility of guiding academic departments towards filling the gap found in their quality related performance.

The present study can help academic departments build up an internal system for quality management to improve the level of the educational programs and other elements affecting them. Such an outcomes-related system involves precise specifications for quality, the identification of good practice as well as of learning deficiencies and obstacles, performance follow-up, suggestions for development and enhancement, and the systematic review and development of processes for establishing effective policies, strategies and priorities to support continuing improvement. In this study, only academic departments' members were selected to express their views concerning program quality. Therefore, further research might be needed to investigate more stakeholders of the programs, eg, the students, the graduates, and the labor market, society, etc. with the aim of improving and developing the program to cope with their needs and meet the quality requirements.

\section{References}

Abou Taleb,M. (2009), Critical Success Factors for Implementing E-learning Programs in Hospitality Education, World Journal of Tourism,Leisure\&Sports,3(4)pp23-37

Al-Turki, U., \& Duffuaa, S. (2003). Performance measures for academic departments. International Journal of Educational Management, 17(7), 330-338.

Badri, M. A., Selim, H., Alshare, K., Grandon, E. E., Younis, H., \& Absulla, M. (2006). The Baldrige Education Criteria for performance excellence framework: Empirical test and validation. International Journal of Quality \& Reliability Management, 23(9), 1118-1157.

Bogue, E. G. (1998). Quality assurance in higher education: The evolution of systems and design ideals. New Directions for Institutional Research, 1998(99), 7-18.

Bosselman R. H. (1996). Current perceptions of hospitality accreditation. FIU Hospitality Review, 14(2), 77-84.

Harvey, L. (1994), "Continuous quality improvement: a system-wide view of quality in higher education", System Wide Curriculum Change 
Harvey, L. (2004). The power of accreditation: Views of academics. Journal of Higher Education Policy and Management, 26(2), 207-223.

Horng, J.-S., \& Teng, C.-C. (2011). Cross-cultural quality measurement of undergraduate hospitality, tourism and leisure programmes: Comparisons between Taiwan and the USA. Journal of Hospitality, Leisure, Sport and Tourism Education, 10(1), 49-62.

Horng, J.-S., Teng, C.-C., \& Baum, T. (2009). Evaluating the quality of undergraduate hospitality, tourism and leisure programmes. Journal of Hospitality, Leisure, Sport and Tourism Education, 8(1), 37-54.

Horng, J.-S., Teng, C.-C., Lee, M.-H., \& Liu, Y.-A. (2006). Higher educational evaluation in UK: Implications on professional evaluation of hospitality, tourism and leisure undergraduate studies in Taiwan. Journal of Tourism Studies, 12(4), 273-294.

Mizikaci, F. (2006). A systems approach to program evaluation model for quality in higher education. Quality Assurance in Education, 14(1), 37-53.

NAQAAE "National Authority for Quality Assurance and Accreditation of Education", (2009), National Academic Standards for the faculties of tourism and hotels graduates.

Nichols, M. A. (2002). Development of a quality assurance system for e-learning projects. Paper presented at the ASCILITE.

Pereda, M., Airey, D., \& Bennett, M. (2007). Service quality in higher education: The experience of overseas students. Journal of Hospitality, Leisure, Sport \& Tourism Education, 6(2), 55-67.

Nunnaly, J. (1978) Psychometric theory, New York: McGraw-Hill

Pfeffer, N., Coote, A. (1991), Is Quality Good For You? A critical review of Quality Assurance in the Welfare Services, Institute of Public policy Research, London.

Rao, S. S., Solis, L. E., \& Raghunathan, T. S. (1999). A framework for international quality management research: Development and validation of a measurement instrument. Total Quality Management, 10(7), 1047-1075.

Robbins, D. (2005). Quality assurance. In D. Airey, \& J. Tribe (Eds.), An International Handbook of Tourism Education (pp. 451-468). Oxford, England: Elsevier.

Sahney, S., Banwet, D. K., \& Karunes, S. (2004). Conceptualizing total quality management in higher education. The TQM magazine, 16(2), 145-159.

Srikanthan, G., \& Dalrymple, J. F. (2007). A conceptual overview of a holistic model for quality in higher education. International Journal of Educational Management, 21(3), 173-193.

Stufflebeam, D. L. (2000). The CIPP model for evaluation. In D. L. Stufflebeam, G. F. Madaus, \& T. Kellaghan (Eds.), Evaluation models: Viewpoint on educational and human services evaluation (2 ${ }^{\text {nd }}$ ed., pp. 279-317). Dordrecht, The Netherlands: Kluwer Academic.

Winn, B. A., \& Cameron, K. S. (1998). Organisational quality: an examination of the Malcolm Baldrige National Quality Framework. Research in Higher Education, 39(5), 491-512.

$$
\begin{aligned}
& \text { تقييم جودة قسمى السياحة والفنادق } \\
& \text { دراسة حالة لكلية السياحة و الفنادق - جامعة مدينة السادات }
\end{aligned}
$$

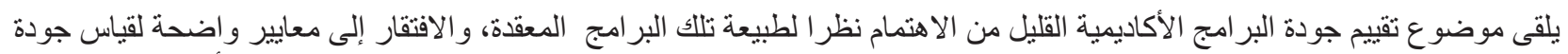

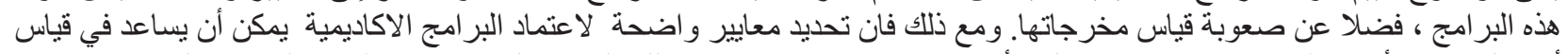

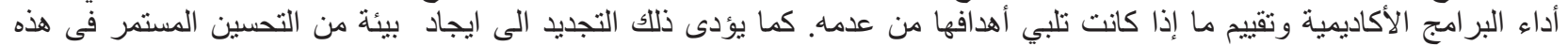

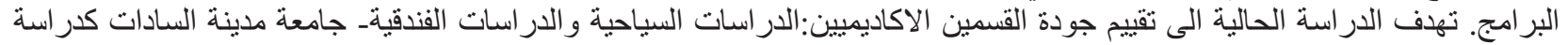

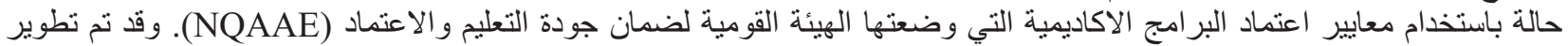

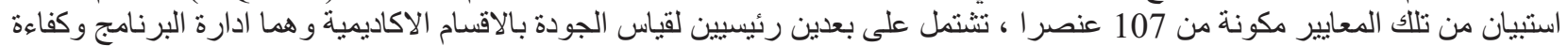

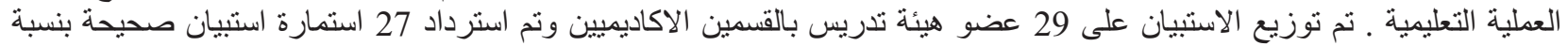

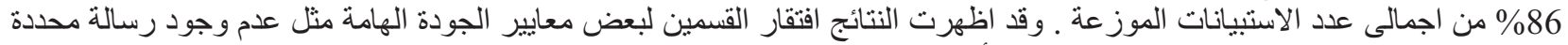

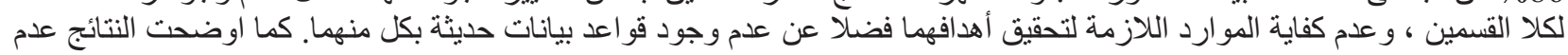

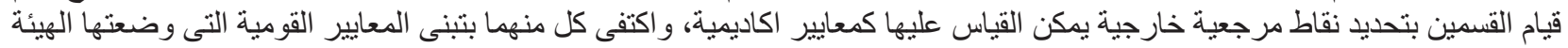

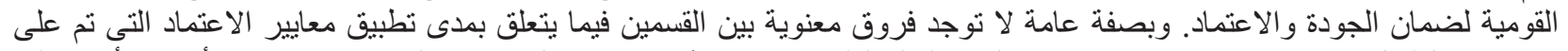

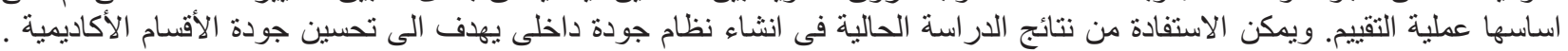

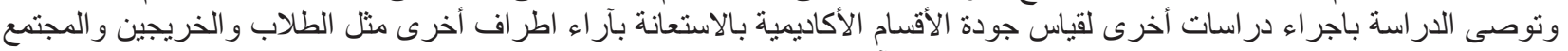

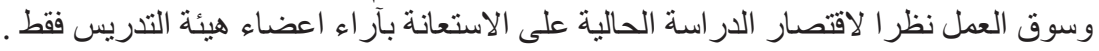

